\title{
THE SYSTEMATIZATION AND CLASSIFICATION OF SOCIO-ECONOMIC PROBLEMS IN HIGHER EDUCATION
}

\author{
Anatolii Lomonosov' ${ }^{1}$, Oksana Lomonosova ${ }^{2}$, Iryna Nadtochii ${ }^{3}$
}

\begin{abstract}
Economic, social, demographic, ideological, and political instability in Ukraine has become the cause of a whole range of socio-economic problems in higher education. It requires studying their composition, interdependence, and impact on higher education. Nowadays different ranges of socio-economic problems in higher education in Ukraine are being discussed in the literature. Despite a large number of publications, the systematization of socio-economic problems in higher education in Ukraine is not given due attention. For a better idea of their composition, interdependence, and focus, it is useful to systematize them and develop their catalogue. The purpose of the study is to identify approaches to systematization and classification of socio-economic problems in higher education in Ukraine. Methodology. The following theoretical methods of socio-economic phenomena and processes learning as abstract-logical (methods of induction and deduction, analysis and synthesis, analogy, generalization, comparison, system-structural, abstraction), content analysis, empirical research (description and comparison), systematization of scientific knowledge were used in research. To systematize socio-economic problems in higher education, their catalogue was developed, on the basis of which these problems were directly systematized and classified. Results. The major socio-economic problems and contradictions in higher education in Ukraine, as well as in European countries and the United States, were determined and analysed in the given study. The analysis of the recent studies and publications on socioeconomic problems in higher education showed that there are currently no proposals for the formation of their single system. On the basis of research, the catalogue containing forty-one most important socio-economic problems in higher education in Ukraine has been developed. For the visual representation of the system of problems and causal relationships between them, a conceptual map has been proposed. For that, the problems that are directly related to the purpose of the study are selected from the catalogue. As an example, a conceptual map of socio-economic problems caused by inadequate funding for higher education, as well as problems linked with the formation and maintaining its principal resource - academic staff - was developed. To classify the socio-economic problems in higher education in Ukraine, a $3 \times 3$ matrix is proposed, in which problems in higher education are grouped depending on the place of their manifestation and the place of solution. The places of manifestation and places of the solution are defined as: a sphere of higher education, other spheres, a sphere of higher education, and other spheres simultaneously. It allows us to identify the problems, solution to which society puts on higher education only, and those that require joint efforts. Distribution of problems by the determined features identifies their targeting and the degree of responsibility of the higher education system for their solution. The practical relevance of the given study is to provide further research on the state of higher education and problems of its functioning. The approaches proposed to the systematization and classification of socio-economic problems in higher education in Ukraine can be applied to other countries as well.
\end{abstract}

Key words: higher education, problems in higher education, systematization of problems in higher education, classification of problems in higher education, graphical methods of systematization, graphical methods of classification, conceptual map of the main socio-economic problems in higher education in Ukraine.

JEL Classification: $\mathrm{H} 12,123,015$

\footnotetext{
Corresponding author:

${ }^{1}$ Admiral Makarov National University of Shipbuilding, Kherson Branch, Ukraine.

E-mail: avloe@gmail.com

${ }^{2}$ Admiral Makarov National University of Shipbuilding, Kherson Branch, Ukraine.

E-mail: alvirginis@gmail.com

${ }^{3}$ Admiral Makarov National University of Shipbuilding, Kherson Branch, Ukraine.

E-mail:nira@ukr.net
} 


\section{Introduction}

The socio-economic, ideological, and political transformations taking place in any society inevitably directly or indirectly affect the state and functioning of its higher education system. Thus, the impact of the 2008 global financial crisis (the Great Recession) on higher education in many countries proved to be longlasting, and its negative consequences persist (See, e.g., Mitchell at all, 2017; Selingo, 2018; Gunn, 2018).

In post-Soviet countries, including Ukraine, the functioning of higher education is significantly obstructed by economic, socio-demographic, ideological, and political instability, which restrains the resolution of accumulated socio-economic problems.

Nowadays a lot of philosophical, pedagogical, psychological, informational and other problems concerning higher education are widely and thoroughly discussed. But socio-economic problems are the ones that are most often in the spotlight. And although they are paid particular attention, as evidenced by a number of publications; scientists, managers, and practitioners operate diverse ranges of these problems, which differ by their composition, number, focus, relation to certain higher education institution (HEI) or to their system in general.

In our opinion, to ensure further research on problems and the state of higher education, it is essential to systematize and classify its socio-economic problems. These issues are considered in the example of Ukraine, a big country in Europe in terms of territory and population, with an industrial-agrarian economy and a favourable geographical location. Though precisely its higher education has accumulated a whole complex of socio-economic problems, some of which have become chronic. Many of these problems had arisen long before Ukraine gained independence, but so far, they have remained unresolved.

\section{Literature review}

The analysis of current research and publications concerning socio-economic problems in higher education in Ukraine revealed that there is no single system of socio-economic problems in higher education. Although the analysis of these problems has always had enough attention (Ishchenko, 2014; Drobnokhod, 2012 etc.), their totality is represented differently in the studies on these problems in higher education. For example, in the analytical study of the current state, problems, and assignments for the promotion of higher education in Ukraine (Zhyliaiev at all, 2015), a range of problems, their causes, and possible solutions are thoroughly considered. But the general system of these problems is absent.

S. O. Sysoieva, analysing in detail the development of education in Ukraine in its historical and institutional formation, also outlines a range of problems inherent in higher education. Most of them she explains by the fact that Ukraine "remains a country with a transition economy, and its society is going through a period of transformation" (Sysoieva, 2013). At the same time, the author has not formed an integral system of socioeconomic problems.

Sometimes the system of problems in higher education is considered too simplified. N. R. Stepanova, for instance, considers problems of funding, quality, availability, and graduates' employment as the most important ones (Stepanova, 2013).

Quite often only some of the problems are considered. In The White Book of the National Education of Ukraine, which is intended "to highlight the most urgent problems ("blank spots"), to determine their causes and to offer the ways of their solving or alleviating," the attention is focused on the social and pedagogical problems (Aleksieienko at all, 2010). Socio-economic problems are also observed in the studies (Lomonosov, Lomonosova, 2007a; Lomonosov, Lomonosova, 2007b; Lomonosova, 2004), but they consider only some of them.

There is no systematization of these problems in the abovementioned publications, as well as in many others which analyse socio-economic problems in higher education. The only exception is the classification of social problems in higher education, offered by Ye. Mykhaliova. It is built on the grouping of problems according to three levels - macro-, meso-, and microlevel. "The first level determines the character and discrepancies of 'coupling' of the education systems on the world or regional (in its wide sense, for example, Europe as a region) level. The second level is connected with the positioning of higher education in a certain society, and the effective implementation of its social functions. The third level affects social problems of the subjects of education, which are determined by their affiliation to the sphere of higher education" (Mikhaileva, 2011).

Thus, although the analysis of socio-economic problems in higher education is given enough attention, many issues are awaiting their solution. It also concerns the matter of systematization of socio-economic problems in higher education in Ukraine, which remains unresolved.

\section{The methodology of research}

The methodological support of further research on socio-economic problems in higher education in Ukraine requires, first of all, their systematization and classification. It will help to select them out of the general range of problems in higher education, to determine connections among them, to establish appropriate causal relationships and internal ordering, classify them according to the most significant peculiarities.

It is appropriate to systematize socio-economic problems of higher education in Ukraine in two stages. 
At the first one, it is necessary to compile a catalogue of problems, that is, to form their list. Any catalogue (from the Greek katálogos - list) is a list of objects, concepts, arranged in a specific order to facilitate their search. In principle, the list of socio-economic problems in higher education may be disorderly. The primary objective at this stage of systematization is the separation of socioeconomic problems from the general range of problems in higher education (social, political, structural, educational, pedagogical, psychological, etc. (Vahovich at all, 2014; Aktualni problemy, 2016; Yurchenko, 2010) and the formation of their maximum possible set.

The direct systematization of problems should be the second stage. Systematization usually means: the process or mental activity on combining the scattered knowledge about objects (phenomena) into a single scientific system, the establishment of their unity (Kostiukevych at all, 2017; Systematyzatsiia, 2019); "Action (or their consistency), due to a particular range of unattached components becomes a range of connected components" (Dutsiak, 2010); "placement of investigated phenomena or objects in a specific order, sequence with the identification of their interconnection and subordination" (Savitskaya, 2000; Kolchkov, 2015), etc.

The task of systematization of socio-economic problems in higher education in Ukraine should be the presentation of a system of these problems with a description of the links between them. Since the list of problems is numerical, it is necessary to determine at least the main ones and to identify their interconnection and subordination.

In addition to systematizing socio-economic problems in higher education in Ukraine, their classification is important as well. It should be noted that the latter concept is interpreted in various ways by different authors, and the relationship between systematization and classification is also perceived ambiguously.

Classification is: an action to classify, that is, divide objects, phenomena or concepts into classes, groups, etc. by commonalities (Yakushkin, 2012; A great dictionary, 2001); process consisting of ordering by the arrangement of objects, phenomena or concepts in classes, subclasses, and ranks, depending on their general features (Kolchkov, 2015); the distribution of objects, concepts, titles into classes, groups, ranks according to the common features (Economic encyclopedia, 2000); a system whose components are linked by subordination ties (subordination of one component to another) and coordination (the relation between a number of components that are subordinate to one component) (Dutsiak, 2010), etc.

If systematization is perceived as an action, activity, process, then classification, as seen from the above definitions, is also interpreted as action, activity, process, and as a result of this process as a system of distribution of objects, phenomena or concepts into classes, groups, etc.
It is necessary to note that sometimes the terms "systematization" and "classification" are used as synonyms (see, for example (Yakushkin, 2012; Nesterov, 2016). But most often classification is understood as one of the principal, most significant types of systematization (Mizherikov, 2004; Demina, Przhilenskiy, 2017) as "a form of systematization by means of a certain distribution of these objects into groups" (Subbotin, 2001).

Thus, the systematization of socio-economic problems in higher education in Ukraine involves their unified system construction, which reflects the set of the considered problems, and also characterizes the relations of subordination and coordination. The main thing here, in our opinion, is the visual representation of problems interrelations and interdependence that can be achieved through the use of graphic methods. It will allow visualizing the range of problems, placing them in a specific order and sequence, that will provide a clear indication of their logical subordination and relationships, as well as determine the impact of the solution of each problem on others.

In contrast, the classification of socio-economic problems in higher education in Ukraine should provide an opportunity to distribute their entire range on separate grounds. Obviously, socio-economic problems in higher education, regardless of their particularity, are an integral part of all socio-economic problems of society. That is why they can be classified according to the same grounds as all the problems (the dependence of problems on their subjects; the role in the society development; the time of action; scale; urgency; the level of understanding; the degree of solvability etc.). But first of all, it is necessary to form groups of problems according to the signs, which are the most relevant for higher education.

\section{Presentation of the main material}

\subsection{Major socio-economic problems and contradictions in higher education in Ukraine}

Currently, in higher education, one of the main problems is the chronic underfunding of HEI, which started in the Soviet era. The lack of funds leads to the formation of many other problems and contradictions. Therefore, this problem and the directly related ones should be given the foremost attention.

One of the most significant problems caused by underfunding is the insufficient salary level of the academic staff. Since they are the central resource and the main driving force of HEI, then, all the socioeconomic problems affecting the lecturers' activities should be under review in the first place.

The insufficient level of remuneration for lecturers leads to the low social status of academic staff and other employees of HEIs, promotes bribery, brain drain 
to large cities of Ukraine and abroad. The latter is of particular importance for regional HEIs, which often face staffing challenges.

Increasing the salary level for lecturers would enable the most talented youth to be involved in scientific and pedagogical work, which would help to solve the problem of a high average age of the academic staff members. The development of an effective system of evaluation and material stimulation of the academic staff activities, aimed at intensifying their scientific and methodological work, which requires additional funds is essential too.

Essential economic problems of higher education are: the outdated physical infrastructure, which requires immediate renewal, lack of computer equipment and up-to-date software, the inconsistency of the system of professional development and re-training of lecturers and current requirements. There are difficulties with the coverage of current HEI payments.

Issues in higher education deepen under the influence of adverse factors of the environment, first of all negative demographic processes, price increase for goods and services in Ukraine, HEI graduates with a degree in science and technology being unclaimed, refusal of enterprises to fund scientific research due to drop in production level, etc. Thus, the demographic crisis has led to a reduction in the number of secondary schools' leavers, resulting in a decrease in the number of students and a fall in incomes derived from the paid educational services, starting from the 2007-2008 academic year. At the same time, HEIs face the task of substantial improvement in the quality of the specialists' training, which also requires increased funding.

The shortage of funds prompts HEIs to introduce a strict austerity regime that only favours their retention, without resolving existing problems. The tight financial situation in Ukraine and limited opportunities for the state budget make it challenging and even impossible to resolve these problems.

There are several groups of contradictions that are caused by existing problems in higher education nowadays. Among the contradictions, first and foremost, it should be noted that the academic staff salary level is inconsistent with the complexity, responsibility, and importance of their work; they have an insufficient material interest to improve the quality of training. Solving the problem of insufficient salary level for lecturers is the solution of this contradiction.

The second contradiction is that, on the one hand, the constant funding cuts require a strict austerity from HEI, including the reduction of labour costs for academic staff, as now in Ukrainian HEIs labour costs with accruals reach $80-85 \%$ of the total cost. On the other hand - increasing the interest in the outcome of their work, improving the quality of training, as well as rejuvenation of the staff implies an increase in salary level and, consequently, extra funding.
Using the limited funds to solve specific problems results in freezing and even deepening of the other ones. For example, targeting the vast majority of funds to a significant increase in salary levels may leave unresolved such problems as the need for equipment modernization, repair of buildings, increased funding for scientific research, organization of fellowship programs for lecturers in the leading HEIs of Ukraine and the world, library collections update, etc.

\subsection{Major problems in higher education in Europe and the USA}

It should be noted that most of the abovementioned problems are inherent not only in higher education in Ukraine. In other countries of the world, one of the principal problems is underfunding too; it associates with the quality of higher education, financial relations with the state authorities. The lack of funds has led to the emergence and spread of economic and social problems in higher education in European countries and the United States. The financing problem has been worsened by the 2008 global crisis, which has reduced both the volume and the share of government funding. The strategy of reducing the support of public colleges and universities has been chosen by many countries in Europe as well as by the United States (Carpentier, 2015; Mitchell at all, 2017 , etc.). As a result, a tuition increase made a college education unaffordable to children of middle-class parents in the USA (Standler, 2009).

At the same time, a discussion about the role and place of public funding has continued for a long time. Despite the development and spread of the idea of an entrepreneurial university, many scholars, specialists, and public figures believe that education, including higher education, is primarily a public good (Locatelli, 2018; Marginson, 2016, and others). Understanding higher education as a public good necessitates equitable and equal access to higher education for everyone who has the necessary level of pre-training and regardless of his social and economic status. In terms of higher education, social equity will not be achieved through access to further education alone. In order to fully enjoy the benefits of higher education and to contribute to the society and economy in which they live, individuals need to complete their program of study (Trends in Global, 2009). In the report of the Task Force on Higher Education and Society in the developing countries, which was created by the World Bank and the United Nations Organization, there was formed an idea, that higher education "seems to be to combine tolerance at points of entrance with rigor at the point of exit" (World Bank, 2000). It requires from each society to insure that all of its young citizens have both the prerequisites (academic and economic) and ongoing support to participate successfully, but the corresponding mechanisms are rarely used (Trends in Global, 2009). 
At that time, economic realities, commercialization of higher education have led to the transformation of modern institutions of higher education into market actors operating in conditions of fierce competition, competing for students, including from those abroad, the best lecturers, accumulation of funds from different sources, support of reputation (competition in international ratings) (Mendoza, 2005). Here one can add competition in providing the students with a broader range of specializations and specializations, as well as price competition. Universities are now very nervous about two things: their public profile and future demand (Schuller at all, 2018).

Reducing public funding leads to that "in a globalized world, universities are increasingly market-driven and market-funded. They operate under the constraints of decreasing public funding both in developed and developing countries. Financial restrictions are accompanied by other kinds of restriction on academic freedom and institutional autonomy, and this happens both in liberal democracies and in authoritarian regimes and conflict-affected settings" (Selenica, 2018).

For decades, increased commercialization of higher education has led to negative consequences and a number of problems. Among them: an erosion of quality, freezing new enrolment in programs, overcrowded lecture halls, elimination of distance education centres, reduction of the permanent workforce, including lecturers, and hiring part-time or temporary workers, lack of trained professionals, insufficient or outdated library holdings, computing, and Internet connectivity, curriculum that avoids the matter of critical thinking, etc. All that happens simultaneously with increasing tuition fees and insufficient loan and scholarship schemes (Trends in Global, 2009; Mitchell at all, 2015; Selenica, 2018).

Many scholars draw attention to the fact that the condition and development of higher education should be tied to long-term state goals, national economic results and improved management efficiency. Here the formation of the strong middle class, the development of entrepreneurship and the training of skilled workforce for a competitive economy, the positive impact of higher education on reducing crime, social activities strengthening, better health, which benefits the communities are given as the positive results (Tandberg, Laderman, 2018; Mitchell at all, 2015; Mitchell at all, 2017).

Cuts and inadequate support for higher education may limit higher education's ability to support states in accomplishing their goals (Tandberg, Laderman, 2018). Therefore, in the scholarly literature and in the press, the idea of raising the funding level for higher education is expressed. B. Johnstone and P. Shroff-Mehta write that "higher education should continue to require state support". Simultaneously, less expensive forms of higher education have to be created, and financial assistance should be provided for those who require it (Johnstone,
Shroff-Mehta, 2001). J. Granados considers that "states must provide the necessary financing so that universities can carry out their public-service function (Granados, 2011). J. Denham pays attention to the fact that the English government needs to take back control of funding and use it to incentivize universities to provide the diverse courses that students and the economy need (Changing the emphasis, 2018).

It must be noted that in the vast majority of European countries, except Great Britain, public funding continues to play a dominant role. It was confirmed by the study of funding profiles in 28 European university systems (Pruvot at all, 2015). Even after public funding cuts because of the financial crisis its share in the European universities was 3/4 (Estermann, 2017). In 2013, the share of public financing of the European countries was distributed in this way (Table 1). The smallest share of public funding ranged from approximately $40 \%$ in England to the biggest $95 \%$ in Iceland and Denmark (Pruvot at all, 2015).

\section{Table 1}

Distribution of European countries by the share of public funding

\begin{tabular}{|l|c|c|c|c|c|}
\hline Public funding share, \% & $51-60$ & $61-70$ & $71-80$ & $81-90$ & $91-100$ \\
\hline Number of countries & 2 & 4 & 7 & 8 & 2 \\
\hline
\end{tabular}

Source: based on (Pruvot at all, 2015)

Lack of funds is felt in economically powerful countries as well. In England, nearly 25\% of universities were in deficit last year. The number of universities with operating deficits rose gradually. Across the UK, the number of reporting deficits was 10 in 2015-16, in 2017-18 increased to 32, compared with 24 the year before (Adams, 2019).

In the USA, the state spending on higher education has maintained a fairly steady downward trajectory, indicating that higher education is capturing far fewer funds than it did in the past. The share of state spending for higher education has also declined, with $8.2 \%$ in 1990 and only 5.2\% in 2017 (Tandberg, Laderman, 2018).

It is clear that in the current circumstances public funding is not enough for universities functioning and development. Raising funds from other sources is also necessary. But private funding must be additional rather than substitutive (Carpentier, 2015). The problem here is to determine the amount of public funding sufficient for affordable university funding and ensuring equitable access to high-quality higher education. It relates to all countries without exception, including Ukraine.

Emphasizing the importance of public funding and assuming that higher education is a public good, S. Bergan focuses on the difficulty in identifying how much public funding is reasonable and on what conditions (Bergan, 2005). In his opinion, society believes higher education 
is vital to its development, and that a country as a whole should have advanced knowledge of a wide area of disciplines, society should also stimulate its members to seek higher education in as many fields as possible including those where higher education graduates will not have access to more highly paid jobs, e.g. school teachers. Ensuring sufficient quality standards of training is the indisputable condition for public funding. Though the decision that private institutions and programmes are recognised because they are of sufficient quality should not automatically mean they have a right to receive public funds (Bergan, 2005).

A significant problem is the employment of graduates, access to more highly paid jobs, study fees for students which are considered, as a rule, in the context of correlation between the costs and benefits of higher education. Study fees serve as an investment in human capital, in which both the student and society are interested.

Among the problems connected with the employment of the higher education graduates in Europe, V. Kostoglou and. S. Paloukis distinguish two major ones. The first is that many of the graduates are obliged to work in jobs not vocationally related to their subject of study. According to their data, in some countries those are more than 50\%. Another one is the significant rate number of graduates' unemployment in some countries (Kostoglou, Paloukis, 2015).

\subsection{The systematization of socio-economic problems in higher education in Ukraine}

\subsubsection{The catalogue of socio-economic problems in higher education in Ukraine}

To deepen understanding of the whole range of socio-economic problems and to analyse the state and trends of the higher education system development, it is necessary to have a single catalogue covering the most important of them.

An analysis of a large number of publications on the problems in higher education in Ukraine has made it possible to identify those of a socio-economic nature. As a result, a catalogue has been composed, which includes forty-one most important socio-economic problems in higher education in Ukraine. These problems in another form (in the form of a two-dimensional square matrix used to classify problems) are shown in Table 2, which is given below.

\subsubsection{The variants of systematization of socio- economic problems in higher education in Ukraine}

One of the possible variants of the system of essential problems and contradictions in higher education in Ukraine can be graphically represented as follows (Figure 1). It provides an idea about a totality of issues, describes the principal causal relationships between them. Though it must be admitted that the display of only the main problems makes it somewhat limited. Thus, the figure shows only eighteen out of forty-one socio-economic problems contained in the catalogue. It is difficult to show in the figure all the complex of socioeconomic problems in higher education in Ukraine.

Therefore, while studying the socio-economic problems in higher education in Ukraine, depending on the objectives, it is desirable to select the issues from the catalogue, that are directly related to the purpose of the study. In Figure 1, the main problems caused by underfunding of higher education, as well as problems associated with the formation and maintenance of its primary resource - academic staff, were chosen.

It is clear that, for example, when studying the socio-economic problems of students, the variety of significant issues looks different. In addition to funding problems, the lack of computer equipment and software, the high average age of lecturers and their inadequate qualifications, it is also necessary to take into account socio-psychological problems of youth related to the students' adaptation to HEI, their socialization, selfaffirmation, formation of social maturity, organizational skills, ability to work in a team, etc., socio-economic problems (scholarships, support for young families), social and pedagogical problems of students related to the individual abilities in learning, problems to spur students to a self-conscious and persistent thirst for knowledge, and so on.

Similarly, in the analysis and systematization of socioeconomic problems of higher education in a certain country, causal relationships among the problems inherent in this country should be identified. It should be taken into account that, as shown in sections 3.1 and 3.2, the problems in higher education in European countries, the United States and Ukraine are practically the same. But their importance and attitudes towards them are different in different countries. For example, such problems as bribery, the lack of real autonomy of HEIs, the problems of covering running costs, etc. are relevant for post-soviet countries. Issues related to the employment of graduates became very serious in the southern part of Europe (Spain, France, Italy). These problems are less obvious in north European countries (Kostoglou, Paloukis, 2015). To simplify the conceptual map of problems and make it comprehensible insignificant problems may not be displayed.

\subsection{The classification of socio-economic problems in higher education in Ukraine}

It is worth noting that systematization does not give the chance to identify the problems that have common characteristics for the most critical features of higher education. In our opinion, for solving socio-economic problems in higher education, the most important 


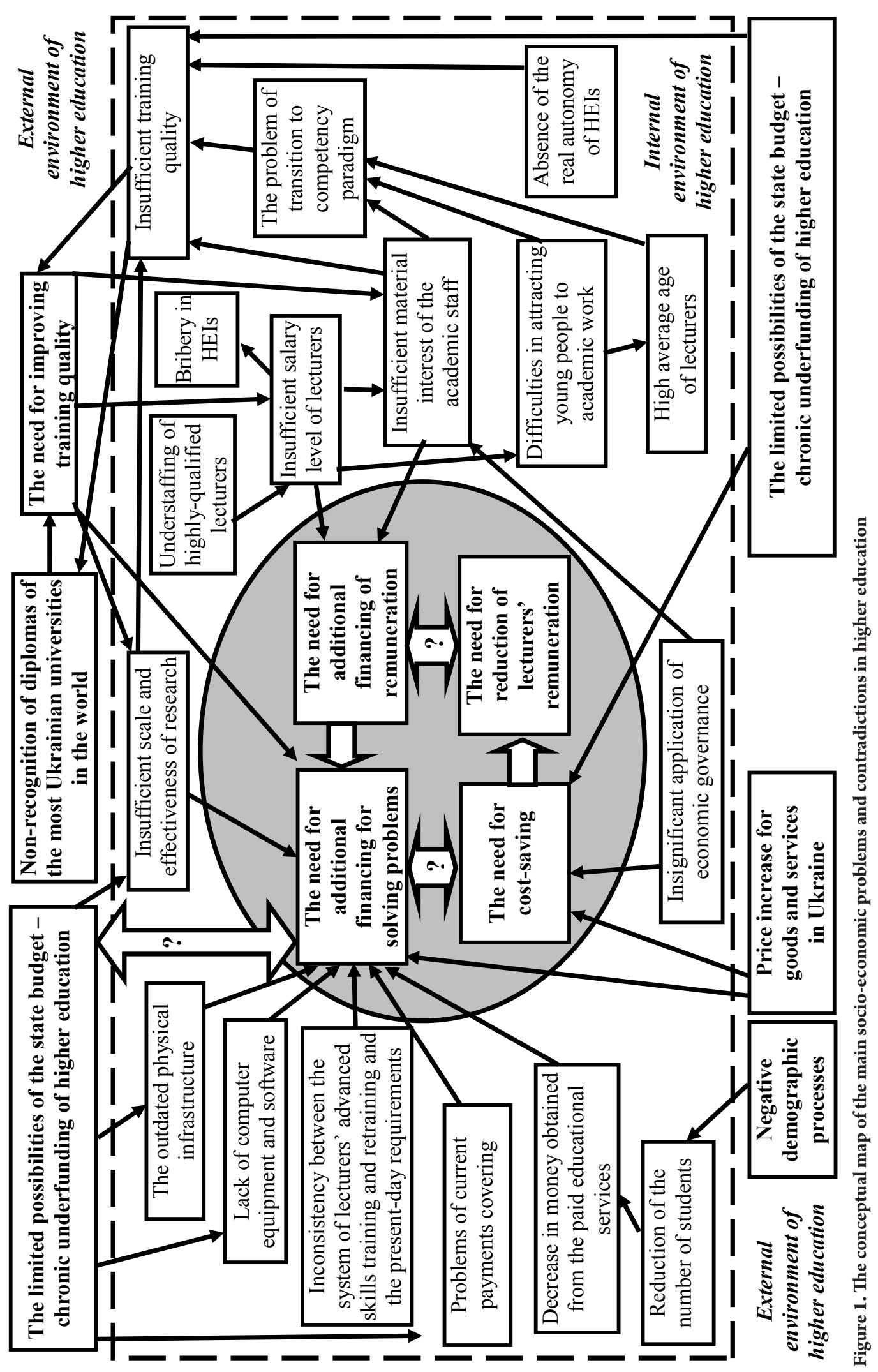


thing is to distinguish the spheres of their immediate manifestation and their solution, as well as to determine the level of importance for each problem. This is because not all the problems are generated in higher education itself, a significant part of them affects other spheres of society. These problems solutions are in the sphere of higher education and beyond it. Therefore, the classification of socio-economic problems according to these two grounds seems to be extremely important.
It matters to higher education since it allows determining their own problems or these problems' expansion onto other spheres of social life, as well as to determine whether their solution depends on higher education or on other spheres. Such systematization is practical because it gives the chance to specify the direction vectors of this or that problem, to determine their targeting and the degree of responsibility of higher education for their solution.

Table 2

Classification of socio-economic problems of higher education in Ukraine according to the spheres of their manifestation and solution

\begin{tabular}{|c|c|c|c|c|}
\hline \multirow{2}{*}{\multicolumn{2}{|c|}{$\begin{array}{l}\text { Systematization } \\
\text { signs }\end{array}$}} & \multicolumn{3}{|c|}{ Spheres of problem solution } \\
\hline & & Higher education & Higher education, other spheres & Other spheres \\
\hline 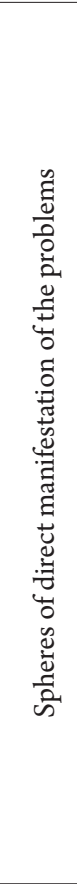 & 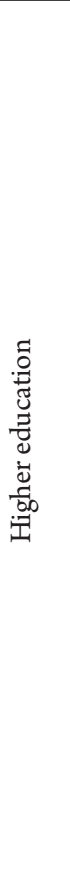 & $\begin{array}{l}\text { 1. Insignificant application of } \\
\text { economic governance }\end{array}$ & $\begin{array}{l}\text { 1. Absence of real autonomy of HEIs } \\
\text { 2. Need to improve the management efficiency of } \\
\text { HEIs } \\
\text { 3. Insufficient salary level of lecturers } \\
\text { 4. Insufficient material interest of the academic } \\
\text { staff to improve their work } \\
\text { 5. Inadequate qualification of lecturers } \\
\text { 6. The high average age of lecturers } \\
\text { 7. Inconsistency between the lecturers' advanced } \\
\text { skills training and retraining system and the } \\
\text { present-day requirements } \\
\text { 8. Low social status of the academic staff of HEI } \\
\text { 9. Difficulty in involving young people in } \\
\text { education and research work } \\
\text { 10. Bribery in HEIs } \\
\text { 11. Understaffing of highly-qualified lecturers at } \\
\text { the regional HEIs and brain-drain to the big cities } \\
\text { of Ukraine and abroad } \\
\text { 12. Poor physical infrastructure } \\
\text { 13. Lack of computer equipment and software } \\
\text { 14. The problem of covering current payments } \\
\text { 15. Socio-economic problems of students (grants, } \\
\text { young families support programs) }\end{array}$ & $\begin{array}{l}\text { 1. Chronic underfunding of } \\
\text { higher education, the need to } \\
\text { apply its new forms and models } \\
2 \text {. Reduction in the number of } \\
\text { entrants and students because of } \\
\text { the demographic crisis } \\
\text { 3. Decrease in money obtained } \\
\text { from the paid educational } \\
\text { services } \\
\text { 4. Social and pedagogical } \\
\text { problems of students, connected } \\
\text { with their individual potential of } \\
\text { education and upbringing. }\end{array}$ \\
\hline & 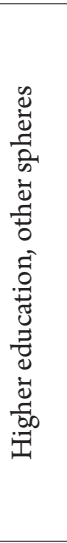 & $\begin{array}{l}\text { 1. Socio-psychological problems } \\
\text { of the young people concerning } \\
\text { the adaptation of students at } \\
\text { HEIs, socialization, self-assertion, } \\
\text { formation of social maturity, } \\
\text { organizational and social skills, } \\
\text { team work, etc. } \\
\text { 2. Stimulating students to } \\
\text { conscious self-education and } \\
\text { constant thirst for knowledge } \\
\text { 3. Inadequate upbringing } \\
\text { 4. Non-recognition of the } \\
\text { diplomas of the most Ukrainian } \\
\text { universities in the world }\end{array}$ & $\begin{array}{l}\text { 1. Insufficient level of training quality } \\
\text { 2. The need for transition to competency } \\
\text { paradigm } \\
\text { 3. The mass character of higher education, lack of } \\
\text { intellectual selection of entrants } \\
\text { 4. The low motivation of young people to study } \\
\text { 5. Insufficient scale and effectiveness of research } \\
\text { at HEIs } \\
\text { 6. Insufficient integration of education, practice } \\
\text { and science } \\
\text { 7. Insufficient level of humanization in education }\end{array}$ & $\begin{array}{l}\text { 1. Insufficient level of education } \\
\text { accessibility } \\
\text { 2. Underestimation of HEIs } \\
\text { activities for socio-economic } \\
\text { development of the country } \\
\text { 3. Insignificant financial } \\
\text { opportunities of enterprises to } \\
\text { fund research } \\
4 \text {. The contrariety of enterprises } \\
\text { to innovations because of the } \\
\text { low level of production base and } \\
\text { insufficient innovation culture of } \\
\text { society }\end{array}$ \\
\hline & 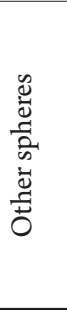 & $\begin{array}{l}\text { 1. Obsolete teaching contents, } \\
\text { overloaded with pseudo- } \\
\text { scientific, far from reality material } \\
2 . \text { Insufficient practical skills of } \\
\text { graduates }\end{array}$ & $\begin{array}{l}\text { 1. An imbalance between the training of specialists } \\
\text { and the needs of the labour market } \\
\text { 2. Difficulties in finding employment for } \\
\text { graduates, insecurity of their first job } \\
\text { 3. Unequal opportunities to get the desired speciality } \\
\text { due to disproportional distribution of HEIs and } \\
\text { licensed quantity of students across the country } \\
\text { 4. The need to ensure social mobility of HEIs' graduates }\end{array}$ & \\
\hline
\end{tabular}


All the range of socio-economic issues that are in the catalogue can be presented by a two-dimensional square matrix $3 \times 3$ (Table 2 ).

The matrix contains three rows and three columns. The problems, given in these three rows are grouped according to the sphere of their manifestation: in the first row one can see those that are clearly manifested only in the sphere of higher education, in the third one - those that do not or rarely appear in the HEIs activities. They appear in other spheres of public life. The second row contains problems that are manifested simultaneously (although with varying intensity) both in higher education and in other spheres.

In the matrix columns, socio-economic problems are distributed according to the spheres of their solution: in the first one there are those that can be solved in the higher education system, in the second one - those whose solution depends not only on higher education but also on other spheres. The third column contains problems whose solution does not depend on higher education, although it can be initiated by it.

Therefore, the proposed matrix contains nine squares. In the first one, there are problems that are manifested directly in higher education. They must be resolved in this sphere as well. The second square contains the majority of problems that are directly manifested in higher education. But at the same time, their solution depends not only on higher education but also on other spheres. The third square includes problems that are manifested in higher education but the latter has virtually no impact on them and they have to be resolved outside it.

Not referring to the problems included in other squares, the given matrix cannot be considered as a completely formed one. It includes socio-economic problems in higher education in Ukraine, which are most often discussed. The inclusion of some problems in these or those squares can give rise to doubts. In addition, the situation may change over time. All this requires adjusting the matrix.

\section{Conclusions}

According to the results of the Ukrainian economic and other literature sources analysis, the catalogue containing forty-one most important socio-economic problems in higher education in Ukraine has been formed. It creates the primary basis for further research, including the systematization and classification of the considered issues.

The systematization of socio-economic issues in higher education in Ukraine should be carried out on the basis of the developed catalogue. At the same time, depending on the purpose of the study, it is necessary to choose the range of problems from the catalogue, which will form a system, reflecting interconnections and subordination of problems.

The classification of socio-economic problems in higher education in Ukraine can be carried out on various grounds. In our opinion, the classification of problems according to the spheres of their direct manifestation and the spheres of their solution is the most important now. Graphically, it is appropriate to present such a classification in the form of a twodimensional square matrix of $3 \times 3$, which clearly shows where exactly (in higher education, in higher education and in other spheres or only in other spheres) there are problems. In this classification, there have been determined the problems, whose solution our society relates only to higher education, and those that require joint efforts of different spheres of our society for their resolving, and the ones which higher education cannot resolve. The approaches proposed to the systematization and classification of socio-economic problems in higher education in Ukraine can be applied to other countries.

Further research must include an expert assessment of the importance of each problem and determining the impact of its solution on improving the functioning of the higher education system.

\section{References:}

Mitchell, M., Leachman, M., \& Masterson, K. (2017). A Lost Decade in Higher Education Funding: State Cuts Have Driven Up Tuition and Reduced Quality (Research Report). Center on Budget and Policy Priorities. Retrieved from: https://vtechworks.lib.vt.edu/bitstream/handle/10919/83618/TuitionReducedQuality.pdf

Selingo, J. (2018, September 21). How the Great Recession changed higher education forever. The Washington Post. Retrieved from: https://www.washingtonpost.com/education/2018/09/21/how-great-recession-changedhigher-education-forever/?utm_term=.ef54a5196d88

Gunn, D. (2018, October 4). State spending on higher education still hasn't recovered from the recession. And progress on that front may be slowing. Pacific Standard. Retrieved from: https://psmag.com/education/statespending-on-higher-education-still-hasnt-recovered-from-the-recession

Ishchenko, A. Yu. (2014). Hlobalni tendentsii i problemy rozvytku osvity: naslidky dlia Ukrainy: analitychna zapyska [Global trends and problems of education development: consequences for Ukraine: a policy brief]. Retrieved from: http://www.niss.gov.ua/articles/1537/ (in Ukrainian)

Drobnokhod, M. Sohodennia i problemy vyshchoi shkoly Ukrainy [The present day and problems of higher education of Ukraine]. Akademiia nauk vyshchoi shkoly Ukrainy. Retrieved from: http://www.anvsu.org.ua/index. files/Articles/Drobnokhod2.htm (in Ukrainian)

Zhyliaiev, I. B., Kovtunets, V. V., \& Siomkin, M. V. (2015). Vyshcha osvita Ukrainy: stan ta problemy [Higher education of Ukraine: state and problems]. Kyiv: Naukovo-doslidnyi instytut informatyky i prava Natsionalnoi 
akademii pravovykh nauk Ukrainy, Instytut vyshchoi osvity Natsionalnoi akademii pedahohichnykh nauk Ukrainy. (in Ukrainian)

Sysoieva, S. (2013). Osvitni reformy: osvitolohichnyi kontekst [Educational reforms: educational context]. Teoriia i praktyka upravlinnia sotsialnymy systemamy: shchokvartalnyi naukovo-praktychnyi zhurnal, 3, 44-55. (in Ukrainian) Stepanova, N. R. (2013). Aspekty vzaimodeistviya sistemy vysshego professionalnogo obrazovaniya i rynka truda [Aspects of interrelationship of higher professional education system and labour market]. Sovremennye problemy nauki i obrazovaniya. Retrieved from: https: //www.science-education.ru/ru/article/view?id=11377 (in Russian) Aleksieienko, T. F., Anishchenko, V. M., Ball, H. O. ta in. (2010). Bila knyha natsionalnoi osvity Ukrainy [The White Book of National Education of Ukraine]. Kyiv: Inform. Systemy. (in Ukrainian)

Lomonosov, A. V., \& Lomonosova, O. E. (2007a). Vyiavlennia rezerviv zmenshennia chyselnosti shtatnykh posad naukovo-pedahohichnykh pratsivnykiv vyshchykh navchalnykh zakladiv [Identifying the reserves of reducing the number of academic staff positions at HEIs]. Aktualni problemy ekonomiky, 3, 114-122. (in Ukrainian)

Lomonosov, A. V., \& Lomonosova, O. E. (2007b). Planuvannia rivnia vnutrishnovuzivskoi unifikatsii navchalnykh planiv u vyshchykh navchalnykh zakladakh III-IV rivniv akredytatsii [Planning the degree of curricula unification at HEIs of the third-fourth level of accreditation]. Visnyk Khmelnytskoho natsionalnoho universytetu, Seriia: Ekonomichni nauky, 1(92), 217-222. (in Ukrainian)

Lomonosova, O. E. (2004). Rozrakhunky trudomistkosti navchalnoi roboty, shcho vidnosytsia do pevnoi spetsialnosti, $u$ vyshchomu navchalnomu zakladi [Calculations of labour intensity of educational work at certain speciality at HEI]. Zbirnyk naukovykh prats. Mykolaiv: UDMTU, 1(394), 111-116. (in Ukrainian)

Mikhaileva, E. H. (2011). Sotsyalnye problemy vysshego obrazovanyia: sovremennye vektory razvertyvanyia [Social problems of higher education: modern vectors of deployment]. Vcheni zapysky KhGU „NUA”, XVII, 30-43. (in Russian)

Vahovich, I. M., Ishchuk, L. I., \& Pyrih, S. O. (2014). Stan i problemy vyshchoi osvity v Ukraini [State and problems of higher education in Ukraine]. V. 1, 63-69. (in Ukrainian)

Aktualni problemy vyshchoi profesiynoi osvity Ukrainy (2016). [Actual problems of higher vocational education in Ukraine]. Materialy IV Mizhnarodnoi konferenzii 17.03.2016. Kyiv: NAU. Retrieved from: http://kpppo.nau.edu.ua/ files/Konfer.pdf (in Ukrainian)

Yurchenko, V. (2010). Aktualni psykholohichni problemy vyshchoi shkoly v Ukraini [Actual psychological issues of higher education in Ukraine]. Aktualni pytannia psykholohichnoho zabezpechennia navchalno-vykhovnoho protsesu u vyshchykh navchalnykh zakladakh. Kyiv: KNUIA. (in Ukrainian)

Kostiukevych, V. M., Shynkaruk, O. A., Voronova, V. I., \& Borysova, O. V. (2017). Osnovy naukovo-doslidnoi roboty zdobuvachiv vyshchoi osvity za stupeniamy mahistra ta doktora filosofii [Basics of research for those studying for a master's or PhD degree]. Kyiv. (in Ukrainian)

Systematyzatsiia OPEN SCIENCE [Systematization OPEN SCIENCE]. Retrieved from: https://opnsc.ru/ sistematizaciia.html (in Ukrainian)

Dutsiak, I. Z. (2010). Lohika [Logics]. Kyiv. Retrieved from: https://westudents.com.ua/glavy/35126-71-zagalnuyavlennya-pro-sistematizatsyu.html (in Ukrainian)

Savitskaya, G. V. (2000). Analiz hozyaystvennoy deyatelnosti [Analysis of economic activity]. Minsk. (in Russian)

Kolchkov, V. I. (2015). Metrologiya, standartizatsiya i sertifikatsiya [Metrology, standardization and certification]. Moskva. Retrieved from: http://micromake.ru/old/msisbook/msisstand1c.htm (in Russian)

Yakushkin, B. V. (2012). Klassifikatsiya (sistematizatsiya) [Classification (systematization)]. Bolshaya Sovetskaya Entsiklopediya. Retrieved from: https://slovar.cc/enc/bse/2004779.html (in Russian)

Busel, V. T. (ed.) (2001). A great explanatory dictionary of modern Ukrainian. Kyiv. (in Ukrainian)

Mochernyi, S. V. (ed.) (2000). Economic encyclopedia. Kyiv. (in Ukrainian)

Nesterov, A. V. (2016). Sistematizatsiya (klassifikatsiya) ekspertiz na primere ekspertizy $v$ tamozhennyih tselyah [Systematization (classification) of expert examinations on the example of the examination for customs purposes]. Moskva. (in Russian)

Mizherikov, V. A. (2004). Slovar-spravochnik po pedagogike [Dictionary-reference book on pedagogy]. Moskva. (in Russian)

Demina, L. A., \& Przhilenskiy, V. I. (2017). Logika, metodologiya, argumentatsiya v nauchnom issledovanii [Logics, methodology, reasoning in research]. Uchebnik dlya aspirantov. Moskva. (in Russian)

Subbotin, A. L. (2001). Klassifikatsiya [Classification]. Moskva. (in Russian)

Carpentier, V. (2015). Political economy of higher education and socio-economic crises: global and national perspectives. Paper presented at the conference on 'The Theory of Regulation in Times of Crisis,' Paris, 9-12 June. Retrieved from: http://theorieregulation.org/colloques/colloque-rr-2015/programme-rr2015/ (Accessed March 2, 2016).

Mitchell, M., Leachman, M., \& Masterson, K. (2017). A Lost Decade in Higher Education Funding: State Cuts Have Driven Up Tuition and Reduced Quality (Research Report). Center on Budget and Policy Priorities. Retrieved from: https://vtechworks.lib.vt.edu/bitstream/handle/10919/83618/TuitionReducedQuality.pdf

Standler, R. (2009). Financial Problems in Universities. Retrieved from: http://www.rbs0.com/univ09.htm 
Locatelli, R. (2018). Education as a public and common good: Reframing the governance of education in a changing context. Education Research and Foresight Working Papers. Series, No. 22. Paris, UNESCO. Retrieved from: https://unesdoc.unesco.org/ark:/48223/pf0000261614

Marginson, S. (2016). Public/private in higher education: a synthesis of economic and political approaches. Working paper no. 1. Published by the Centre for Global Higher Education, UCL Institute of Education, London WC1HOAL.

Trends in Global Higher Education: Tracking an Academic Revolution. A Report Prepared for the UNESCO 2009 World Conference on Higher Education / Philip G. Altbach, Liz Reisberg, Laura E. Rumbley.

World Bank (2000). Higher Education in Developing Countries: Peril and Promise, Washington D.C: World Bank.

Mendoza, P. (2005). Academic Capitalism and Doctoral Student Socialization: a Case Study: an abstract of the thesis of Doctor Education. N. Y.

Schuller, T., Tuckett, A., \& Wilson, T. (2018). A National Learning Entitlement: Moving Beyond University Tuition Fees. London: Centre for Learning and Life Chances in Knowledge Economies and Societies.

Selenica, E. (2018) Universities between the state \& the market, Development policy, commercialization \& liberalization of higher education, SAIH. Retrieved from: https: //www.saih.no

Mitchell, M., Palacios, V., \& Leachman, M. (2015). States are Still Funding Higher Education below Pre-Recession Levels. Journal of Collective Bargaining in the Academy. Volume 0 National Center Proceedings 2015. Retrieved from: https://thekeep.eiu.edu/cgi/viewcontent.cgi? article $=1524 \&$ context=jcba

Tandberg, D., \& Laderman, S. (2018). Evaluating State Funding Effort for Higher Education. MHEC policy brief. National Forum on Higher Education for the Public Good at the University of Michigan.

Johnstone, D. B., \& Shroff-Mehta, P. (2001). Finansirovanie i dostupnost vyisshego obrazovaniya: mezhdunarodnoe sravnitelnoe issledovanie oplatyi obucheniya i mer finansovoy podderzhki [Higher education finance and accessibility : an international comparative examination of tuition and financial assistance policy]. Universitetskoe upravlenie - praktika i analiz, 2(17), 17-32. (in Russian)

Granados, J. (2011). The Challenges of Higher Education in the 21st Century, GUNi Newsletter 5/11. Retrieved from: http://www.guni-rmies.net/news/detail.php?id=1725

Changing the emphasis on university funding (2018). The Guardian. Retrieved from: https://www.theguardian.com/ education $/ 2018 / \mathrm{feb} / 21 /$ changing-the-emphasis-on-university-funding

Pruvot, E. B., Claeys-Kulik, A.-L., \& Estermann, T. (2015). Designing strategies for efficient funding of universities in Europe (DEFINE Project Paper). Brussels: European University Association.

Estermann, T. (2017). Trends in university funding in Europe and the impact on universities and management. EUA.

Adams, R. (2019, Thu 21 Mar). Nearly 25 \% of English universities in deficit last year, figures show. The Guardian. Retrieved from: https://www.theguardian.com/education/2019/mar/21/england-universities-in-deficit-figuresfinancial-pressure

Bergan, S. (2005). «Higher education as a public good and public responsibility”: what does it mean?» In L. Weber and S. Bergan (eds). The public responsibility for higher education and research, Council of Europe Higher Education Series, No. 2, Council of Europe Publishing, Strasbourg.

Kostoglou, V., \& Paloukis, S. (2015). Graduates' employment in European Union. Retrieved from: https:9/aetos.it.teithe.gr/vkostogl/files/Publications/dimosieuseis_e26.pdf 